\title{
Brassica Seed Meal Soil Amendments Transform the Rhizosphere Microbiome and Improve Apple Production Through Resistance to Pathogen Reinfestation
}

\author{
Mark Mazzola, Shashika S. Hewavitharana, and Sarah L. Strauss
}

United States Department of Agriculture-Agricultural Research Service (USDA-ARS) Tree Fruit Research Lab, 1104 N. Western Ave., Wenatchee, WA 98801.

Current address of S. L. Strauss: USDA-ARS, Department of Plant Pathology, University of California-Davis, Davis. Accepted for publication 7 November 2014.

\begin{abstract}
Mazzola, M., Hewavitharana, S. S., and Strauss, S. L. 2015. Brassica seed meal soil amendments transform the rhizosphere microbiome and improve apple production through resistance to pathogen reinfestation. Phytopathology 105: 460-469.

Brassicaceae seed meal (SM) formulations were compared with preplant 1,3-dichloropropene/chloropicrin (Telone-C17) soil fumigation for the ability to control apple replant disease and to suppress pathogen or parasite reinfestation of organic orchard soils at two sites in Washington State. Preplant soil fumigation and an SM formulation consisting of either Brassica juncea-Sinapis alba or B. juncea-B. napus each provided similar levels of disease control during the initial growing season. Although tree growth was similar in fumigated and SM-amended soil during the initial growing season, tree performance in terms of growth and yield was commonly superior in $B$.

of four growing seasons. SM-amended soils were resistant to reinfestation by Pratylenchus penetrans and Pythium spp. relative to fumigated soils and corresponded with enhanced tree performance. Phytotoxic symptoms were observed in response to SM amendment at one of two orchard sites, were dependent upon season of application, and occurred in an SM formulationspecific manner. After 2 years, the rhizosphere microbiome in fumigated soils had reverted to one that was indistinguishable from the no-treatment control. In contrast, rhizosphere soils from the SM treatment possessed unique bacterial and fungal profiles, including specific microbial elements previously associated with suppression of plant-pathogenic fungi, oomycetes, and nematodes. Overall diversity of the microbiome was reduced in the SM treatment rhizosphere, suggesting that enhanced "biodiversity" was not instrumental in achieving system resistance or pathogen suppression.
\end{abstract} juncea-S. alba SM-amended soil relative to that in fumigated soil at the end
Additional keywords: microbial diversity, soil resistance, suppressive soil.
Replant diseases of tree fruit are a significant challenge in the establishment of new orchards on sites previously planted to the same or similar species. Although replant disease is influenced by an array of environmental factors, the disease of apple has generally been attributed to biotic factors (42). The identity and consistency of the biological elements reported to incite apple replant disease have varied, with some reports suggesting a contribution by organisms commonly considered to possess a commensal or mutualistic habit rather than to function as plant pathogens (58). However, in-depth analyses of apple replant disease etiology have demonstrated a surprisingly consistent assemblage of pathogens as the primary causal agents, with the complex comprised of fungi, oomycetes, and nematodes $(29,30,36,55)$.

The multifaceted nature of the causal pathogen complex in addition to economic constraints has forced growers to rely on preplant soil fumigation in intensive tree fruit production systems when replanting a site to the same or similar species $(12,53,65)$. In apple, replant disease management has historically relied upon preplant application of broad-spectrum soil fumigants, including 1,3-dichloropropene/chloropicrin, chloropicrin, metam sodium, and methyl bromide $(12,33)$. Chemical soil fumigation often provides effective disease control; however, significant limitations in their

Corresponding author: M. Mazzola; E-mail address: mark.mazzola@ars.usda.gov

http://dx.doi.org/10.1094/PHYTO-09-14-0247-R

This article is in the public domain and not copyrightable. It may be freely reprinted with customary crediting of the source. The American Phytopathological Society, 2015 use include potential increased application costs associated with reregistration criteria (57), regional constraints on the use of particular chemistries (56), and incompatibility with organic production systems. Despite the conflict between soil fumigation and organic farming, the tactic is still the principle means used by organic tree fruit growers for the control of replant disease due to the lack of economically viable management alternatives.

Amendment of soil with particular Brassicaceae seed meals (SM) provides both chemically and biologically mediated control of soilborne pathogens in apple nursery and orchard production systems $(11,62)$. Glucosinolate hydrolysis products generated in response to soil application of SM from Brassica napus and Sinapis alba do not appear to have a significant direct role in suppression of the replant disease causal pathogen complex (41). Rather, SMinduced changes in soil biology appear to direct the suppression of disease caused by specific apple root pathogens, including Rhizoctonia solani (11). Although control of apple root infection by Pythium spp. in response to B. juncea SM is initially a direct function of the glucosinolate hydrolysis product allyl isothiocyanate, long-term suppression was found to function through the resident soil microbiology (62). Apple root infection by Phytophthora spp. can be suppressed by specific B. napus and S. alba SM (38); however, Pythium spp. soil densities and, correspondingly, apple root infection are significantly elevated in response to either SM $(38,39)$.

In previous trials, application of SM from individual Brassicaceae spp. used independently have failed to provide fumigant levels of disease control in apple $(38,43)$. The inability to eliminate disease pressures has always corresponded with incomplete suppression of the pathogen complex that incites replant disease, particularly 
populations of oomycetes (38). Preplant application of a specific SM in conjunction with a postplant mefenoxam soil drench to control Pythium and Phytophthora spp. afforded levels of disease control, tree growth, and yield equivalent to that attained in response to soil fumigation (38). Based on information regarding composition of the pathogen complex and their response to specific Brassicaceae SM amendments $(39,40)$, SM formulations were devised with potential to eliminate the need of the postplant mefenoxam application. For example, in a trial conducted in an organic nursery setting, an SM formulation of $B$. juncea and $B$. napus SM improved initial-year vegetative tree growth and provided disease control at a level equivalent to preplant soil fumigation (38).

As noted above, soil biology has been found to contribute significantly, or solely, to SM-induced disease suppression, depending upon the target pathogen and plant source of the SM $(11,39,41,62)$. Thus, the potential for effective disease control in response to SM amendments could vary between orchard systems and corresponding composition of the resident soil microbial community. In addition, Brassicaceae SM amendments can be an effective herbicide treatment $(22,49,60)$ but also possess potential to cause phytotoxicity in the subsequent crop plant (23). The herbicidal activity of Brassicaceae SM may complicate the establishment of a common effective application strategy across orchard soils that minimizes the potential for phytotoxicity. Plant genotype, expressed as disease tolerance or capacity to recruit a specific battery of rhizosphere-inhabiting microorganisms, may also influence the efficacy of soil biology-mediated disease control (40). The current study was conducted to determine the effect of formulation, application date, and apple rootstock on the efficacy of Brassicaceae SM amendments for the control of apple replant disease in organic orchard systems. In addition, the study examined capacity of the SM treatment to minimize reestablishment of the causal pathogen populations and the potential contribution of altered rhizosphere microbiology to disease suppression.

\section{MATERIALS AND METHODS}

Orchard sites. Studies were conducted at a commercial certified-organic orchard (SMR orchard) near Chelan, WA $\left(47^{\circ} 50^{\prime} 34^{\prime \prime} \mathrm{N} 120^{\circ} 1^{\prime} 17^{\prime \prime} \mathrm{W}\right)$ and at the Washington State University Sunrise (SR) Orchard near Palisades, WA $\left(47^{\circ} 25^{\prime} 08^{\prime \prime} \mathrm{N}\right.$ $\left.119^{\circ} 54^{\prime} 52^{\prime \prime} \mathrm{W}\right)$. The dominant soil type at SMR orchard is Chelan gravelly sandy loam, with a $\mathrm{pH}$ of 4.8 , nitrogen at $105.2 \mathrm{mg} \mathrm{kg}^{-1}$, phosphorous at $124 \mathrm{mg} \mathrm{kg}^{-1}$, sulfur at $30 \mathrm{mg} \mathrm{kg}^{-1}$, and organic matter content of $4.2 \%$ (25). Soil type at SR orchard is a Pogue fine sandy loam, with a pH of 6.9 , nitrogen at $55.3 \mathrm{mg} \mathrm{kg}^{-1}$, phosphorous at $36 \mathrm{mg} \mathrm{kg}^{-1}$, sulfur at $15 \mathrm{mg} \mathrm{kg}^{-1}$, and an organic matter content of $1.2 \%$. The previous apple plantings were removed from the SMR and SR orchards in 2009 and 2006, respectively. The pathogen complexes contributing to disease development were similar at both orchard sites and included Pratylenchus penetrans, Cylindrocarpon spp., Phytophthora cactorum, Pythium spp., and Rhizoctonia spp. $(25,38)$. Primary species of Pythium recovered previously at SMR orchard included Pythium ultimum, P. sylvaticum, and P. irregulare, whereas $P$. ultimum dominated the population at SR orchard. $R$. solani AG-5 and Rhizoctonia sp. AG-G were the principal species of Rhizoctonia recovered from apple roots at the SR and SMR orchards, respectively.

Brassicaceae SM. The SM used in these studies were obtained from B. napus 'Athena' (8), B. juncea 'Pacific Gold' (7), and S. alba 'IdaGold' (6). The process of SM preparation and the chemical characteristics of these SM have previously been reported $(22,62)$. The dominant glucosinolate detected in B. juncea Pacific Gold SM is 2-propenyl glucosinolate (glucosinolate content $[\mathrm{GC}]=176.3$ mmol $\mathrm{g}^{-1}$ ), which yields the biologically active volatile allyl isothiocyanate (AITC). When used as a soil amendment, this SM has suppressed all components of the replant disease pathogen complex, with the exception of Phytophthora spp. (38). The dominant glucosinolate of $S$. alba IdaGold SM $\left(\mathrm{GC}=170.8 \mu \mathrm{mol} \mathrm{g} \mathrm{g}^{-1}\right)$ is 4-OH-benzyl while B. napus Athena $\mathrm{SM}\left(\mathrm{GC}=25.4 \mu \mathrm{mol} \mathrm{g}{ }^{-1}\right)$ contains 3-butenyl, 2-OH-3-butenyl, and 4-pentenyl. Based upon biological activity of the respective Brassicaceae SM toward individual components of the apple replant disease pathogen complex $(38,39)$, two formulations were examined in field trials and consisted of a 1:1 blend of B. juncea and B. napus or B. juncea and $S$. alba SM.

Field trials. The treatments applied at the two field trials are listed in Table 1. Each treatment plot was $10.7 \mathrm{~m}$ in length and $2 \mathrm{~m}$ in width, with five replicates per treatment arranged in a randomized complete block design. The preplant soil fumigation plots were treated with 1,3-dichloropropene-chloropicrin (Telone-C17; Dow AgroSciences, Indianapolis, IN) at a rate of 282 liters ha- $^{-1}$ to a depth of $45 \mathrm{~cm}$, with application performed in September 2009 by a commercial applicator. In field trials, this fumigant enhanced apple tree growth and yield on orchard replant sites as effectively as methyl bromide-chloropicrin, Telone-C35, or metam sodium (T. J. Smith, unpublished data). SM formulations were applied at a rate of 6.7 tons $\mathrm{ha}^{-1}$. Plots were rotovated to incorporate SM to a depth of 15 to $20 \mathrm{~cm}$ and immediately tarped using a clear plastic $152-\mu \mathrm{m}-$ thick sheeting (Sunbelt Plastics, Monroe, LA) to enhance retention of the glucosinolate hydrolysis products in the soil profile. Tarps were removed from the plots after 1 week.

A single SM formulation (B. juncea-S. alba) applied in the spring of planting (29 March 2010) was evaluated at the SMR orchard trial, and the site was planted on 10 May 2010 with 'JonaGold' on G11 rootstock. The SR orchard trial included the two SM formulations (B. juncea-S. alba or B. juncea-B. napus) applied either in the autumn prior to planting (9 September 2009) or the spring of planting (4 April 2010). The orchard was planted on 12 May 2010 with 'Gala' on M9 or G11 rootstock. Each treatment was represented by five replicate plots arranged in a randomized complete block design. Plots were planted with 10 trees per plot with a spacing of $1 \mathrm{~m}$ between trees and $4 \mathrm{~m}$ between rows. Planting material consisted of grafted trees of $15 \mathrm{~mm}$ (5/8 in.) caliper which were obtained from a commercial nursery (Willow Drive Nursery, Ephrata, WA). The sites were managed by the commercial grower at the SMR orchard and by research staff at the SR orchard using standard organic methods in fertility and pest and disease control. SM possessed approximately $5.6 \% \mathrm{~N}, 2 \% \mathrm{~S}, 2 \% \mathrm{P}$, and $1 \% \mathrm{~K}$; thus, plots receiving this treatment at the SR were not fertilized during the initial three growing seasons of these trials. Control and fumigated treatments received a soil surface application of corn gluten (9-0-0) at a rate $0.2 \mathrm{~kg} / \mathrm{m}^{2}$ during October of each year, and all treatments were fertilized in the same manner commencing with the end of the third growing season. Because fertigation was utilized at the commercial SMR orchard, such block-specific fertility management was not feasible at that site.

Evaluation of tree growth and yield. Tree growth was monitored for the eight internal trees in each plot. Growth was assessed for the duration of each trial according to published protocol (38). Briefly, the main stem was marked with latex paint $0.7 \mathrm{~m}$ above the soil line, and measurements of diameter were taken periodically using an electronic caliper at two perpendicular directions. Fruit yield data were acquired in the third and fourth growing seasons for both trials. Fruit were harvested from the internal 8 trees from each 10-tree plot, and yield data were recorded on a per-tree basis.

Root collection and microbial analysis. Root sampling was conducted during October of the initial two (SR orchard) or three (SMR orchard) growing seasons. Root samples were collected at a depth of 5 to $20 \mathrm{~cm}$ from two trees in each treatment plot at a distance 20 to $40 \mathrm{~cm}$ from the tree base. Relative disease control efficacy of soil treatments was assessed by monitoring two components of the replant disease pathogen complex, Pratylenchus penetrans and Pythium spp. Root populations of $P$. penetrans were determined for two 0.5 -g root samples per tree using the water 
extraction and microscopic count method previously described (38). Evaluation of apple root infection by Pythium spp. was conducted by plating root segments $(0.5$ to $1.0 \mathrm{~cm}$ in length) on a Pythium semiselective medium (PSSM) (41) with a total of 20 root segments plated per tree. Plates were incubated at room temperature for microbial growth and examined after 24 and $48 \mathrm{~h}$ to estimate root infection frequency by Pythium spp. The Pythium population recovered from apple roots at the SMR site comprised multiple species; therefore, 20 randomly selected isolates recovered from apple roots for each treatment in this study were identified by sequence analysis of the internal transcribed spacer region. Pythium sp. isolates were subcultured onto fresh PSSM agar and incubated in the dark at $22^{\circ} \mathrm{C}$. After $72 \mathrm{~h}$, isolates were transferred individually to $5 \mathrm{ml}$ of potato dextrose broth amended with ampicillin $\left(100 \mu \mathrm{g} \mathrm{ml}^{-1}\right)$ and grown without aeration for $96 \mathrm{~h}$. DNA was extracted from the mycelium, amplified by polymerase chain reaction (PCR), and sequenced as previously described (38). The sequence identity was obtained by comparison with the GenBank database using the BLAST search tool.

PCR amplification of rhizosphere DNA and pyrosequencing. Root and associated rhizosphere soil samples were collected from the SR orchard on 2 November 2011 for bacterial and fungal community analyses. Samples were obtained as described above from two trees in each control, fumigation, and B. juncea-S. alba SM plot, resulting in a total of 10 samples per soil-apple rootstock treatment. Rhizosphere soil was obtained by initially shaking off loosely adhering soil from the roots and subsequently removing firmly adhering soil either through more vigorous shaking or, if necessary, using a sterile scalpel. For each sample, DNA was extracted from $7 \mathrm{~g}$ of rhizosphere soil using the UltraClean Mega Soil DNA Isolation Kit (Mo Bio Laboratories, Carlsbad, CA) per the manufacturer's protocol. DNA was normalized to a concentration of $20 \mathrm{ng} / \mu \mathrm{l}$ and sent to Research and Testing Laboratory, Lubbock, TX for amplification and pyrosequencing on a 454 Life Sciences GS-FLX instrument (Roche, Indianapolis, IN). Bacterial DNA was amplified using a forward primer composed of a 25-bp 454 A Adapter, an 8-bp barcode, and modified universal bacterial primer 16S-27F (5'-AGR GTT TGA TCM TGG CTC AG-3'), with a reverse primer composed of a 25-bp 454 B Adapter and modified universal bacterial primer 16S-519R (5'-GTN TTA CNG CGG CKG CTG-3'). Fungal DNA was amplified using the 25-bp $454 \mathrm{~A}$ Adapter and an 8-bp barcode followed by the forward primer ITS1F (20) and the reverse primer consisting of the universal primer ITS4 (64) with the 25-bp 454 B Adapter.

Data analysis. Sequences acquired from the FLX sequencing run were further trimmed via a custom scripted bioinformatics pipeline $(24,27)$. In summary, each individual sequence was trimmed to a Q25 average, short reads $<150$ bp were removed, sequences with ambiguous base calls were removed, and sequences with homopolymers exceeding $6 \mathrm{bp}$ were removed. Sequences were then denoised and chimeras removed (13). Operational taxonomic

TABLE 1. Treatments and corresponding application dates employed in field trials conducted at the SMR commercial organic orchard, Chelan, WA and the Washington State University Sunrise (SR) orchard, Palisades

\begin{tabular}{llcc}
\hline & & \multicolumn{2}{c}{ Orchard } \\
\cline { 3 - 4 } Treatment $^{\mathrm{z}}$ & \multicolumn{1}{c}{ Application date } & SMR & $\mathrm{SR}$ \\
\hline No treatment (control) & & $\mathrm{x}$ & $\mathrm{x}$ \\
Telone $=$ C17 soil fumigation & 28 September 2009 & $\mathrm{x}$ & $\mathrm{x}$ \\
B. juncea-S. alba $\mathrm{SM}(\mathrm{Au})$ & 9 September 2009 & $\ldots$ & $\mathrm{x}$ \\
B. juncea-S. alba $\mathrm{SM}(\mathrm{Sp})$ & 29 March (SMR)/ & $\mathrm{x}$ & $\mathrm{x}$ \\
& 4 April (SR) 2010 & & \\
B. juncea-B. napus $\mathrm{SM}(\mathrm{Au})$ & 9 September 2009 & $\ldots$ & $\mathrm{x}$ \\
B. juncea-B. napus $\mathrm{SM}(\mathrm{Sp})$ & 4 April 2010 & $\ldots$ & $\mathrm{x}$ \\
\hline
\end{tabular}

${ }^{\mathrm{z}}$ Seed meal (SM) treatments consisted of a 1:1 formulation of Brassica juncea-Brassica napus or B. juncea-Sinapis alba applied in the autumn prior to $(\mathrm{Au})$ or the spring of $(\mathrm{Sp})$ planting. Telone-C17 $=1,3$-dichloropropenechloropicrin. units (OTUs) were defined after removal of singleton sequences, clustering at 3\% divergence ( $97 \%$ similarity) (14-16). OTUs were taxonomically assigned by comparison with a highly curated database using BLASTn (Research and Testing Laboratory). Sequences were deposited in the GenBank SRA database under Bioproject number PRJNA266254. Samples were rarified to an even depth of 5,000 sequences for bacteria and 3,000 sequences for fungi.

Similarity of fungal and bacterial communities among soil treatments were assessed by subjecting OTU composition to nonmetric multidimensional scaling analysis using the Bray-Curtis distance metric. All analyses were performed using the PAST software package, version 2.14 (21). Measures of fungal and bacterial community diversity were determined using the same statistical package. Species level count data sets of both bacteria and fungi were performed using $\mathrm{R}$ version 3.0.1.

Growth and yield data for eight internal trees in an individual plot were combined to attain a single value for use in analysis. Percent root infection data were transformed to arcsine square root values. Data were analyzed using SigmaStat (version 3.1; Systat Software Inc., Point Richmond, CA). Data were subjected to analysis of variance, and means separation was performed using the StudentNewman-Keuls method.

\section{RESULTS}

At both orchard sites, application of either Brassicaceae SM formulation resulted in suppression of disease and significant increases in tree growth relative to the no-treatment control. In terms of disease control and tree performance, preplant SM amendment was as effective or was more effective than preplant soil fumigation with 1,3-dichloropropene/chloropicrin. At the SMR orchard, soil fumigation and SM amendment resulted in a significant initial positive tree growth response relative to the notreatment control (Fig. 1). However, increase in trunk diameter of trees grown in $B$. juncea-S. alba $\mathrm{SM}$-amended soils was superior to that of either the nontreated control or fumigated soil at the end of four growing seasons (Fig. 1).

At SR orchard, the spring of planting SM amendment resulted in significant tree mortality. When applied in the spring of planting, the $B$. juncea-S. alba SM treatment caused extensive tree mortality (24\%), which was significantly $(P<0.029)$ greater than mortality observed for the control $(5 \%)$ or fumigation $(4 \%)$ treatments. Tree mortality $(14 \%)$ was also observed in plots amended with the $B$. juncea-B. napus SM formulation in the spring of planting but the level of mortality did not differ significantly $(P=0.505)$ from either the control or fumigation treatments. When applied in the autumn prior to planting, the tree mortality rates $(10 \%)$ observed in SMamended soils did not differ significantly $(P>0.733)$ from the fumigation treatment. Thereafter, over the course of four growing seasons, all SM treatments significantly $(P<0.001)$ increased tree growth relative to the no-treatment control, and did so in a manner that was equivalent to that attained in response to preplant 1,3dichloropropene-chloropicrin soil fumigation (Fig. 2). Relative increase in trunk diameter in response to the SM and fumigation treatments was similar for trees grafted to G11 or M9 rootstock. At completion of the trial, growth of Gala-M9 trees trended higher in soil amended with the B. juncea-S. alba SM in the autumn prior to planting compared with the fumigation control, although the difference was not statistically significant. In contrast, with the exception of the control, growth of Gala-G11 trees was markedly similar for all treatments after the initial growing season (Fig. 2).

Cumulative (2012 to 2013) fruit yields were greater in SMamended soil than the no-treatment control and were equivalent to or significantly greater than the yields attained for trees grown in fumigated soil (Tables 2 and 3). At the SMR orchard, soil fumigation did not significantly increase JonaGold-G11 fruit yields compared with the control; however, SM soil amendment resulted in significantly increased fruit yields, which were approximately 
$30 \%$ greater than that attained in fumigated or nontreated orchard soils (Table 2). At SR orchard, all soil treatments significantly improved fruit yields of Gala-G11 trees relative to the no-treatment control (Table 3). With the exception of the spring B. juncea$B$. napus SM soil amendment, all SM treatments resulted in Gala-G11 fruit yields that were significantly greater than yields attained in fumigated soil, and there were no significant differences among SM formulations or application date. For Gala-M9 trees, SM treatments significantly improved yields relative to the no-treatment control but only B. juncea-S. alba SM amendments had yields that were significantly greater than the preplant soil fumigation treatment. Overall, yields from trees grafted on G11 rootstock $\left(8.1 \mathrm{~kg} \mathrm{tree}^{-1}\right)$ were significantly $(P=0.018)$ greater than yields from trees on M9 rootstock $\left(6.3 \mathrm{~kg}\right.$ tree $\left.^{-1}\right)$.

Differential tree growth and yield among soil treatments was associated with the relative suppression of root infection by those causal replant disease pathogens monitored at these orchard sites. For instance, at the end of the initial growing season, both preplant soil fumigation and Brassicaceae SM amendment had suppressed apple root $P$. penetrans densities relative to the no-treatment control at the SMR orchard; however, lesion nematode root densities for the control and fumigation treatments were not statistically different (Table 4). By the end of the second growing season, nematode densities recovered from roots of JonaGold-G11 grown in fumigated soils had increased substantially to a level significantly greater than either the control or SM treatments. After three growing seasons, $P$. penetrans roots densities were significantly lower in the SM treatment relative to all other treatments (Table 4). Similarly, during the initial growing season, soil fumigation and SM amendment suppressed root infection by the diverse Pythium spp. population at the SMR orchard (Fig. 3). As observed in previous studies, the population of Pythium spp. recovered from apple roots included virulent species such as Pythium irregulare, P. sylvaticum, P. abapressorium, and P. ultimum, which accounted for $58 \%$ of the isolates. Other isolates were identified as $P$. attrantheridium, $P$. echinulatum, and $P$. recalcitrans. By the end of the second growing season, the incidence of root infection by Pythium spp. was significantly $(P<0.05)$ higher in fumigated soil than that observed in the SM and control treatments (Fig. 2).
A comparable association between pathogen suppression and relative tree growth and yield was observed at the SR orchard. Preplant soil fumigation and all SM treatments significantly $(P<$ 0.05) suppressed Pratylenchus penetrans apple root densities during the initial growing season (Table 5) relative to the notreatment control, and there were no significant differences among SM formulation, application date, or rootstock. At the end of the second growing season, all SM treatments in concert with G11 rootstock had significantly lower $P$. penetrans root densities than both the control and fumigation treatments (Table 5). When used in conjunction with M9 rootstock, autumn SM applications but not spring SM amendment similarly resulted in prolonged lesion nematode suppression. All SM soil amendments applied in the autumn prior to planting and soil fumigation significantly reduced Pythium root infection relative to the no-treatment control during the initial growing season $(P<0.05)$. Among spring of planting SM treatments, the $B$. juncea-S. alba but not the $B$. juncea-B. napus formulation significantly $(P<0.001)$ suppressed $P$ ythium spp. root infection relative to the control. Pythium spp. root infection frequency differed significantly between rootstocks $(P<0.001)$, and there existed a significant rootstock-soil treatment interaction $(P<0.001)$. Overall, percent Pythium spp. root infection was significantly higher for M9 (27.7\%) than G11 (11.0\%) rootstock and when SM was applied in the spring $(25.5 \%)$ than in the autumn (13.3\%). Pythium spp. root infection detected at the end of the second growing season was low for all soil treatments (0 to 5\%) and there were no significant differences among treatments.

At the SR orchard, the effect of the B. juncea-S. alba SM soil amendment and 1,3-dichloropropene-chloropicrin fumigation on rhizosphere bacterial and fungal community composition was examined at the end of the second growing season. For each replicate (10 replicates per treatment), a mean of 7,368 (range of 5,082 to 10,613 ) bacterial sequences was obtained per sample. Analyses indicated that, at 2 years after orchard establishment, composition of apple rhizosphere bacterial communities detected in the fumigated and control treatments were indistinguishable (Fig. 4). In contrast, at the same sampling time point, the rhizosphere bacterial community recovered from trees grown in SM-treated soil was markedly distinct from either the fumigated or control soil (Fig.

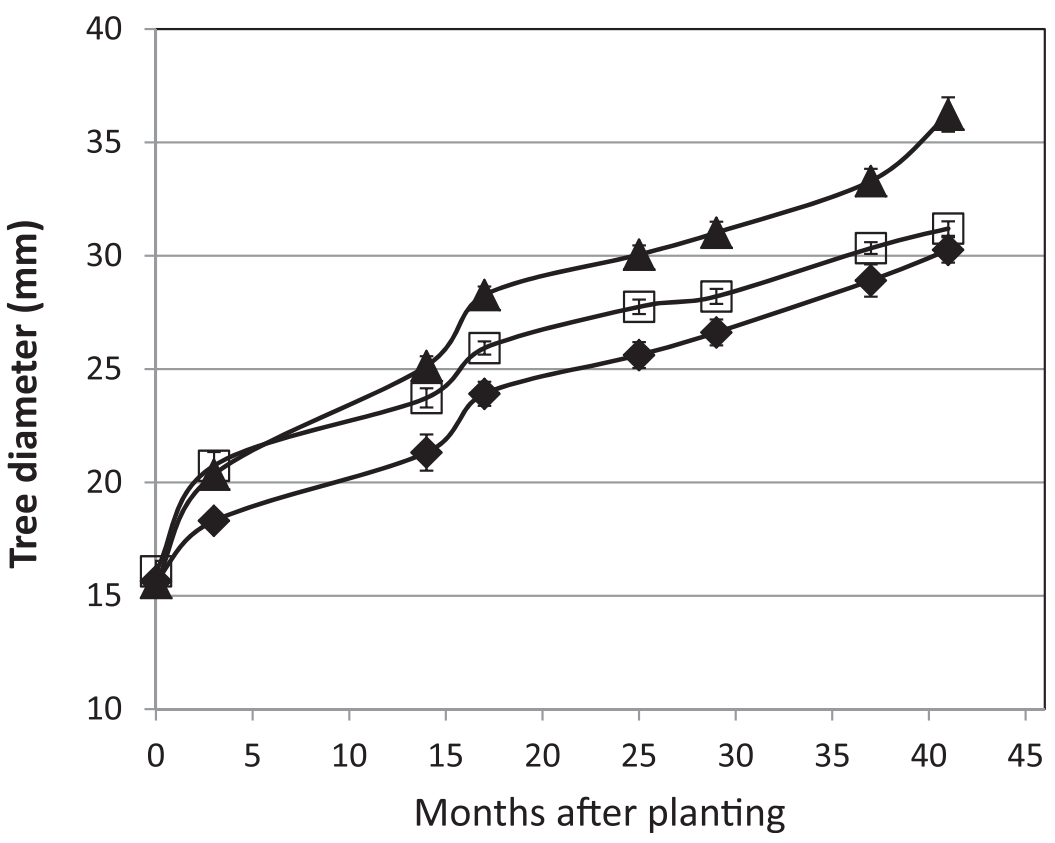

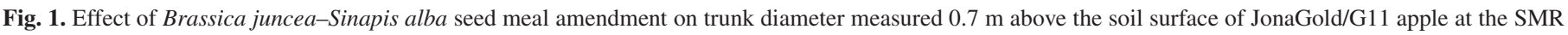

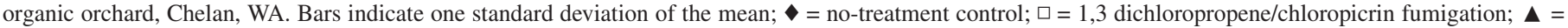
B. juncea-S. alba seed meal soil amendment. 
4). No significant effect of rootstock on the bacterial community composition was detected. Overall, the rhizosphere bacterial community detected in SM-treated soil possessed a lower number of OTUs than was detected in either the control or fumigated soils (Table 6). The SM treatment possessed a rhizosphere bacterial community having lower Shannon and Chaol indices, indicating reduced diversity relative to that detected in the rhizosphere of trees established in nontreated or fumigated orchard soil. The similarity or differences among treatments were not dramatically borne out by
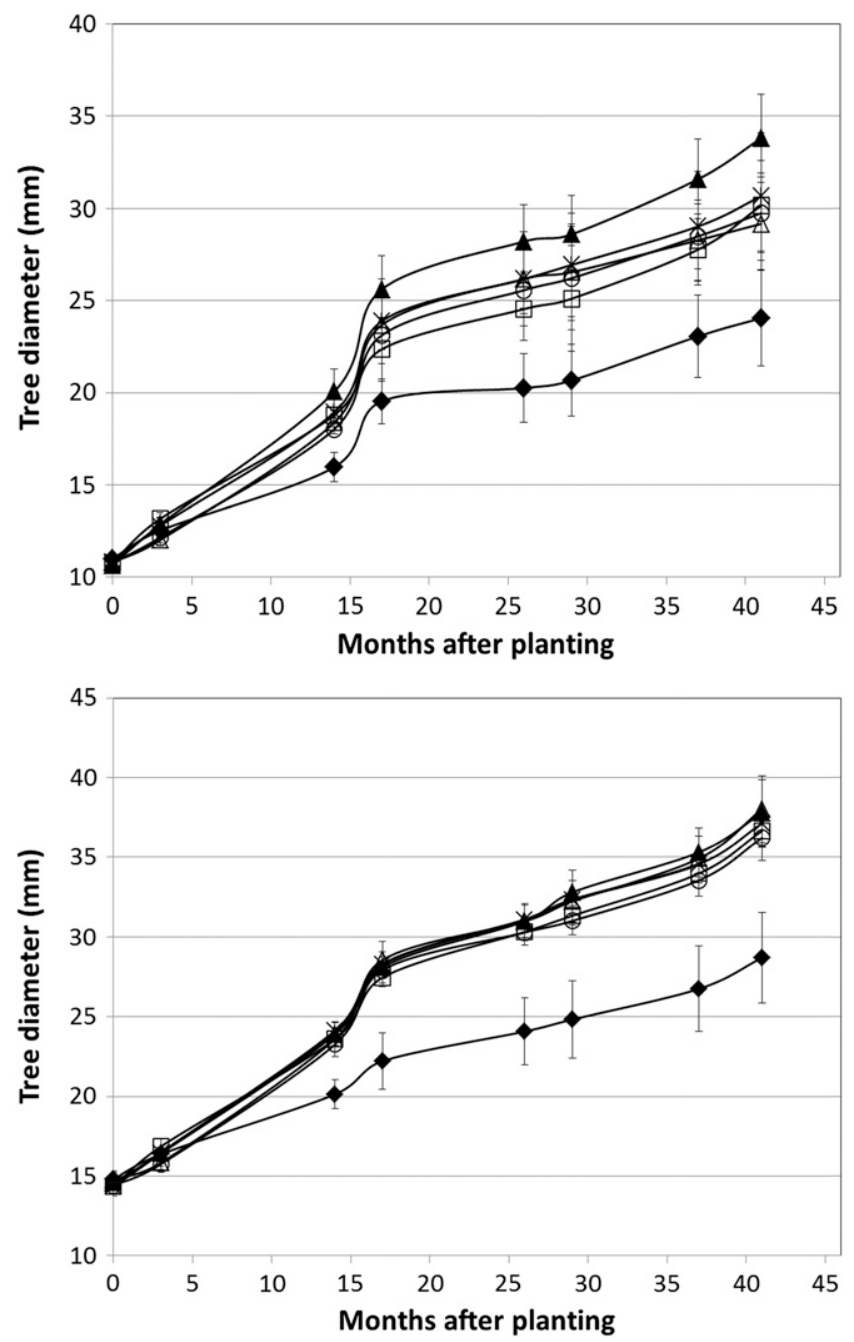

Fig. 2. Effect of preplant soil treatments on trunk diameter measured $0.7 \mathrm{~m}$ above the soil surface of Gala/M9 (top panel) and Gala/G11 apple at the Washington State University Sunrise orchard, Palisades. Bars indicate one standard deviation of the mean; $\forall=$ no-treatment control; $\square=1,3$ dichloropropene/chloropicrin fumigation; $\boldsymbol{\Delta}=$ Brassica juncea-Sinapis alba seed meal (SM) soil amendment autumn prior to planting $(\mathrm{Au}) ; \times=$ B. juncea$B$. napus $\mathrm{SM}$ amendment $\mathrm{Au} ; \Delta=B$. juncea-S. alba $\mathrm{SM}$ soil amendment spring of planting $(\mathrm{Sp}) ; \bigcirc=B$. juncea - B. napus $\mathrm{SM}$ amendment $\mathrm{Sp}$.

TABLE 2. Cumulative yield $\left(\mathrm{kg}_{\mathrm{g}} \mathrm{tre}^{-1}\right)$ of JonaGold/G11 apple on a replant site at the SMR commercial organic orchard, Chelan, WA

\begin{tabular}{ll}
\hline Soil treatment ${ }^{\mathrm{y}}$ & Yield $^{\mathrm{z}}$ \\
\hline Control & $15.6 \mathrm{a}$ \\
Telone-C17 & $16.1 \mathrm{a}$ \\
BjSa SM & $21.2 \mathrm{~b}$ \\
\hline
\end{tabular}

y Seed meal (SM) treatment consisted of a 1:1 formulation of Brassica juncea-Sinapis alba (BjSa) applied in the autumn prior to planting on 10 May 2010. Telone-C17 = 1,3-dichloropropene-chloropicrin.

${ }^{\mathrm{z}}$ Means in the same column followed by the same letter are not significantly $(P>0.05)$ different. examining relative frequencies of bacterial phyla, because these were rather comparable among all treatments, with the exception of Acidobacteria, Gemmatimonadetes, and Proteobacteria, which were detected at higher frequency, and Spirochaetes, detected at lower frequency, in SM-treated relative to the nontreated or fumigated soils.

At a more refined level, significant differences in bacterial community composition were evident among soil treatments. Species of genus Burkholderia, including those classified as Burkholderia phytofirmans, B. fungorum, B. caribensis, B. xenovorans, and $B$. vietnamiensis, were detected in significantly greater abundance in the rhizosphere of apple cultivated in SM-treated soil compared with fumigated or nontreated soil. Streptomyces spp. were less abundant in the SM treatment but other species of Actinobacteria, including members of the genera Arthrobacter, Actinomadura, Actinoplanes, Acidiomicrobium, Curtobacterium, Mycobacterium, and Rhodococcus, were more abundant relative to the rhizosphere bacterial community from fumigated and nontreated control soils. Sulfur-oxidizing bacteria belonging to the genera Deinococcus, Edaphobacter, Thioalkalivibrio, and Thiococcus were significantly more abundant in SM-amended soil. Similarly, bacterial genera involved in various nitrogen-cycling processes such as Bradyrhizobium, Rhodopseudomonas, and Nitrospira were more abundant in the SM treatment. Bacterial genera with a known capacity to metabolize potentially toxic organic compounds were more abundant in the rhizosphere of trees grown in SM-amended soil. For instance, Rhodanobacter lindaniclasticus, which can degrade the pesticide hexachlorocyclohexane (46), was detected exclusively in the rhizosphere of apple cultivated in SM-amended soil. Shinella zoogloeoides, which can utilize pyridine generated by coking plants, pharmaceutical factories, and related industries as a sole carbon source $(2)$, was significantly $(P<0.0029)$ more abundant in the SM treatment. The chlorophenol-degrading bacterium Defluvibacter (18), and Rhodococcus jostii, previously characterized as a polychlorinated biphenyl degrader (35), were both detected at significantly $(P<0.0001$ and 0.0046 , respectively)

TABLE 3. Cumulative yield $\left(\mathrm{kg} \mathrm{tree}^{-1}\right)$ of Gala apple on a replant site at the Washington State University, Sunrise orchard, Rock Island

\begin{tabular}{lcc}
\hline & \multicolumn{2}{c}{ Rootstock $^{\mathrm{y}}$} \\
\cline { 2 - 3 } Soil treatment $^{z}$ & $\mathrm{G} 11$ & $\mathrm{M} 9$ \\
\hline Control & $3.1 \mathrm{a}$ & $3.6 \mathrm{a}$ \\
Telone-C17 & $7.7 \mathrm{~b}$ & $5.6 \mathrm{~b}$ \\
BjBn-Au & $10.1 \mathrm{c}$ & $6.1 \mathrm{~b}$ \\
BjSa-Au & $9.9 \mathrm{c}$ & $7.3 \mathrm{c}$ \\
BjBn-Sp & $7.9 \mathrm{bc}$ & $6.7 \mathrm{bc}$ \\
BjSa-Sp & $9.8 \mathrm{c}$ & $7.5 \mathrm{c}$ \\
\hline
\end{tabular}

y Means in the same column followed by the same letter are not significantly $(P>0.05)$ different.

z Seed meal treatments consisted of a 1:1 formulation of Brassica junceaB. napus $(\mathrm{BjBn})$ or B. juncea-Sinapis alba $(\mathrm{BjSa})$ applied in the autumn prior to $(\mathrm{Au})$ or the spring of $(\mathrm{Sp})$ planting on 12 May 2010. Telone-C17 = 1,3-dichloropropene-chloropicrin.

TABLE 4. Density (number of $\mathrm{g}^{-1}$ root) of Pratylenchus penetrans recovered from roots of JonaGold/G11 apple as influenced by soil treatment at the SMR commercial organic orchard, Chelan, $\mathrm{WA}^{\mathrm{y}}$

\begin{tabular}{lccr}
\hline Soil treatment $^{\mathrm{z}}$ & 2010 & 2011 & 2012 \\
\hline Control & $164 \mathrm{~b}$ & $287 \mathrm{a}$ & $246 \mathrm{~b}$ \\
Telone-C17 & $80 \mathrm{ab}$ & $881 \mathrm{~b}$ & $398 \mathrm{c}$ \\
BjSa-Sp & $9 \mathrm{a}$ & $163 \mathrm{a}$ & $52 \mathrm{a}$ \\
\hline
\end{tabular}

y Means in the same column followed by the same letter are not significantly $(P>0.05)$ different.

z Seed meal treatments consisted of a 1:1 formulation of Brassica junceaSinapis alba $(\mathrm{BjSa})$ applied in the spring $(\mathrm{Sp})$ of planting. Telone-C17 = 1,3dichloropropene-chloropicrin. 
greater abundance from the SM treatment than either the notreatment control or fumigated orchard soil treatments.

Soil treatments induced effects on rhizosphere fungal community composition similar to those observed for rhizosphere bacteria. Multidimensional scaling analysis indicated that, at 2 years after orchard establishment, composition of fungal communities detected in the rhizosphere of apple were highly similar for the fumigation and control treatments (Fig. 5), and there was no statistically significant effect of apple rootstock on fungal community composition. Fungal community diversity in the rhizosphere was lower in SM-treated soil than either fumigation or control treatments (Table 7). The rhizosphere fungal community in the SM treatment possessed a lower number of OTUs as well as lower Shannon and Chao 1 indices relative to those detected in the control and fumigation treatments. The effect of SM treatment on fungal diversity was observed across phyla. Within the phylum Glomeromycota, abundance was lowest in SM-treated soil and the community was composed predominantly (M9 rootstock) or exclusively (G11 rootstock) of Glomus spp. In contrast, the community detected in the rhizosphere of apple cultivated in fumigated or nontreated soil was more diverse and included members of the groups Diversisporales and Paraglomerales as well as unknown groups within the phylum Glomeromycota.

The abundance of additional fungal groups was also influenced by soil treatments. SM treatment reduced basidiomycota abundance in the apple rhizosphere but resulted in an increased abundance of

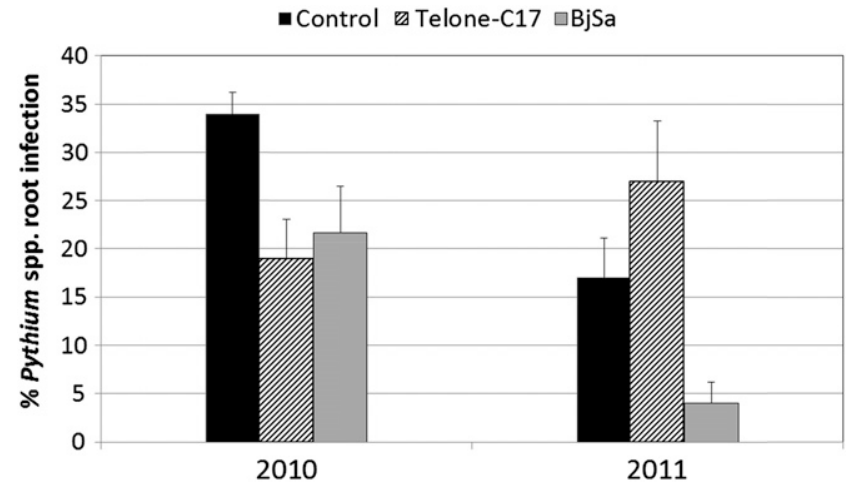

Fig. 3. Effect of soil treatments on infection of JonaGold/G11 apple roots by Pythium spp. at the SMR organic orchard, Chelan, WA, October 2010 and 2011. Bars indicate one standard deviation of the mean. Treatment abbreviations are control $=$ no-treatment control; Telone- $\mathrm{C} 17=1,3$ dichloropropene /chloropicrin preplant soil fumigation; and $\mathrm{BjSa}=$ Brassica juncea-Sinapis alba seed meal soil amendment.

TABLE 5. Density (number of $\mathrm{g}^{-1}$ root) of Pratylenchus penetrans recovered from roots of Gala apple as influenced by rootstock and soil treatment at the Washington State University Sunrise orchard, Rock Island

\begin{tabular}{lrrrrr}
\hline & \multicolumn{4}{c}{ Rootstock $^{\mathrm{y}}$} \\
\cline { 2 - 3 } \cline { 5 - 6 } & \multicolumn{2}{c}{ G11 } & & \multicolumn{2}{c}{ M9 } \\
\cline { 2 - 3 } \cline { 5 - 6 } Soil treatment & & \multicolumn{1}{c}{2010} & & 2011 \\
\hline Control & $391 \mathrm{~b}$ & $188 \mathrm{~b}$ & & $843 \mathrm{~b}$ & $202 \mathrm{~b}$ \\
Telone-C17 & $11 \mathrm{a}$ & $146 \mathrm{~b}$ & & $34 \mathrm{a}$ & $272 \mathrm{~b}$ \\
BjBn-Au & $0 \mathrm{a}$ & $25 \mathrm{a}$ & & $4 \mathrm{a}$ & $86 \mathrm{a}$ \\
BjSa-Au & $0 \mathrm{a}$ & $12 \mathrm{a}$ & & $0 \mathrm{a}$ & $31 \mathrm{a}$ \\
BjBn-Sp & $0 \mathrm{a}$ & $52 \mathrm{a}$ & & $11 \mathrm{a}$ & $215 \mathrm{~b}$ \\
BjSa-Sp & $4 \mathrm{a}$ & $53 \mathrm{a}$ & & $1 \mathrm{a}$ & $247 \mathrm{~b}$ \\
\hline
\end{tabular}

y Root samples were collected at the end of the growing season during October of a given year. Means in the same column followed by the same letter are not significantly $(P>0.05)$ different.

${ }^{\mathrm{z}}$ Seed meal treatments consisted of a 1:1 formulation of Brassica junceaB. napus $(\mathrm{BjBn})$ or B. juncea-Sinapis alba $(\mathrm{BjSa})$ applied in the autumn prior to $(\mathrm{Au})$ or the spring of $(\mathrm{Sp})$ planting. Telone-C17 = 1,3-dichloropropenechloropicrin. zygomycota; in this instance, a group dominated by Mortierella spp. Basidiomycota represented only $6 \%$ of the total rhizosphere fungal community detected in SM-amended soil but comprised approximately 15 to $38 \%$ of the population detected in the control and fumigation treatments. The class Agaricomycetes was detected at relatively uniform levels among soil treatments, whereas the class Tremellomycetes was detected at a higher level (3 to $4 \%$ of total fungi) in the control compared with other soil treatments $(0.2$ to $1.3 \%$ ), regardless of rootstock. Members of the order Mortierellales represented $99 \%$ or greater of the zygomycota population detected in the apple rhizosphere regardless of rootstock or soil treatment. However, although this fungal group represented only $3 \%$ or less of the total fungal population detected in the control or fumigation treatments, it represented 11 and $16 \%$ of the fungal population detected in the rhizosphere of G11 and M9 rootstock, respectively, cultivated in SM-amended soil. The phylum Chytridiomycota represented less than $1 \%$ of the fungal population detected in the apple rhizosphere regardless of soil or rootstock. Chytridiomycota abundance in the apple rhizosphere was highest in fumigated soil and, though Spizellomycetales spp. were detected in the control and fumigation treatments, they were not detected in the SM treatment.

The Ascomycota was the most abundant fungal group detected in the apple rhizosphere across all soil treatments, accounting for 60 to nearly $80 \%$ of the total population. Eurotiomycetes, Pezizomycete, and Gliomastix spp. were identified in the fumigation and control treatments but were absent from the SM treatment. In addition, abundance of Leotiomycetes, Dothideomycetes, and Septogloeum spp. was substantially reduced in SM-treated soil across apple rootstocks. However, Odiodendron spp. represented a significantly $(P<0.001)$ greater component of the Ascomycota population detected in the SM treatment, representing 11.2 and $27.7 \%$ of the population from the rhizosphere of G11 and M9, respectively, but were not detected in the rhizosphere of trees grown in fumigated or nontreated orchard soil. Chaetomium spp. were present in significantly $(P<0.038)$ greater abundance in the SM and fumigation soil treatments than the control.

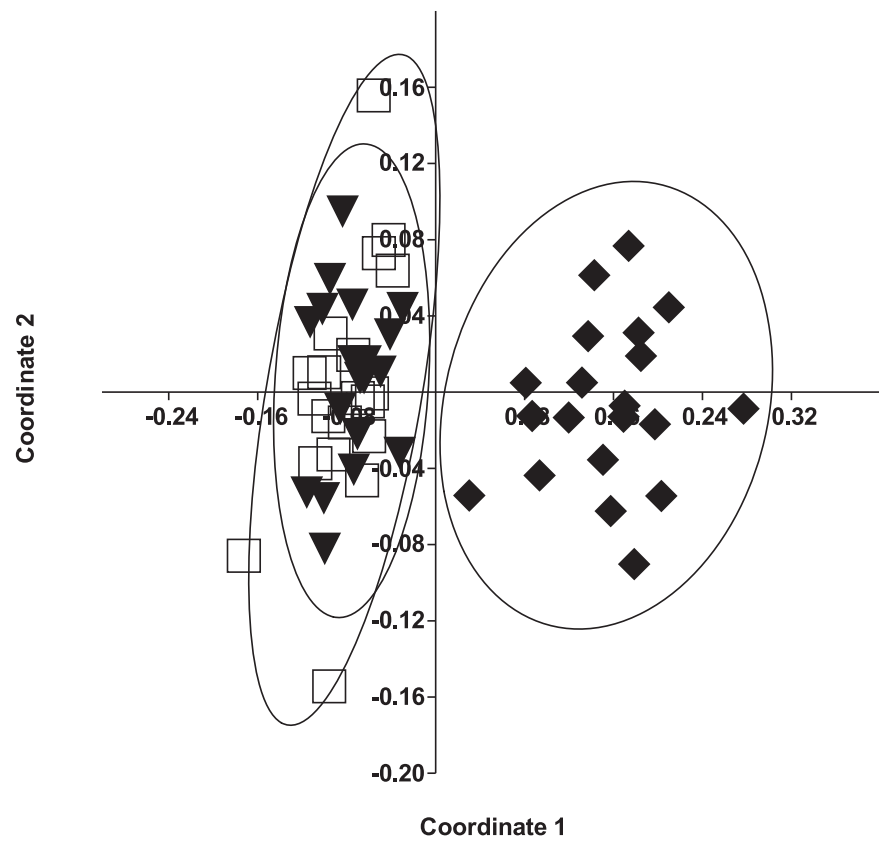

Fig. 4. Effect of preplant orchard soil treatments on bacterial community composition detected in the rhizosphere of Gala apple at the end of the second growing season as assessed by nonmetric multidimensional scaling of operational taxonomic unit (OTU) data using the Bray-Curtis distance metric. OTUs were defined as sequences sharing $\geq 97 \%$ similarity with one another. Ellipses denote $95 \%$ confidence limits; $\square=$ no-treatment control; $\boldsymbol{\nabla}=$ preplant 1,3 dichloropropene/chloropicrin fumigation; $\bullet$ = preplant Brassica junceaSinapis alba seed meal soil amendment. 


\section{DISCUSSION}

These studies, in concert with previous field trials $(39,43)$, demonstrate that Brassica SM formulations can be an effective tool for the management of apple replant disease in both organic and conventional production systems. Findings also suggest that a prescription-based management system could elevate the utility of preplant Brassica SM soil amendments for replant disease control. As observed for soil fumigation, certain parameters of the orchard system must be considered in determining an SM application strategy. For instance, potential phytotoxicity issues were observed in the low organic matter sandy SR orchard soil when SM was applied in the spring of planting that were not evident at the SMR orchard, which possessed a high organic matter content (4.2\%) soil. During decomposition, phytotoxicity is subjected to temporal dynamic change and reductions from sorption and polymerization of toxic chemicals on soil organic matter (34) and chemical transformation by microorganisms (4). This may partially account for phytotoxic symptoms being observed in SR orchard soil with low organic matter content $(1.2 \%)$ and the lack of such symptoms in the SMR orchard soil with high organic matter, as well as the absence of phytotoxic symptoms when SM amendments were applied in the autumn prior to planting. In addition to altered planting strategy, consideration of the appropriate SM formulation in concert with a suitable apple rootstock may resolve the potential for plant injury. At the SR orchard, the Brassica juncea-B. napus SM formulation, when applied during the spring of planting, did not significantly increase tree mortality as a result of phytotoxicity but yielded a superior growth response when used in conjunction with Gala-G11 compared with Gala-M9.

Control of apple replant disease has continued to reply on the use of preplant soil fumigation in both conventional and organic production systems. Soil fumigation is generally perceived to provide optimal orchard performance on replant sites; however, critical analysis of this premise has lacked a means to devise an appropriate comparative system. In this and a previous study (G. Fazio and M. Mazzola, unpublished), the fumigation effect at the SMR orchard was limited to the initial season, with increased growth of 45 to $50 \%$ observed relative to the nonfumigated control, whereas the response in the second growing season was less than $10 \%$. Studies monitoring microbial dynamics over multiple years in fumigated orchard soil have been lacking, thus resulting in an inability to determine the effects of pathogen reinfestation of treated soils on subsequent tree performance. In the current study, preplant B. juncea-Sinapis alba SM soil amendment consistently resulted in improved growth or higher cumulative apple yields than that obtained in response to soil fumigation. Differences in tree performance were associated with treatment effects on relative reinfestation of soils and apple roots by P. penetrans and Pythium spp.

The influence of the preplant SM amendment on enhancing soil resistance to reestablishment of specific soilborne pathogens may have significance in long-term orchard health and productivity. In particular, the lesion nematode not only has been viewed as a significant contributor to replant disease $(29,30,36)$ but also may limit growth and yield of established trees (51). The preplant B. juncea-S. alba SM amendment suppressed lesion nematode root densities relative to the no-treatment control through three growing seasons, while lesion nematode populations in the fumigation treatment had recovered by the end of the second growing season. This difference in nematode reestablishment typically corresponded with enhanced tree growth and yield in SM-amended relative to fumigated soils. These findings not only indicate that the SM-amended soil system provides long-term resistance to pathogen reinfestation of orchard soils but also demonstrate that these root pathogens may limit productivity and economic viability of established orchards as well as new plantings.

The capacity of Brassicaceae SM soil amendment to induce a disease-suppressive orchard soil microbial community was documented previously in greenhouse studies $(11,62)$. Initial suppression of Rhizoctonia solani in response to B. juncea SM amendment was dependent upon production of the bioactive compound allyl isothiocyante $(11,42)$ but long-term suppression was biologically mediated and specifically required amplification of the resident Streptomyces spp. community $(11,42)$. Development

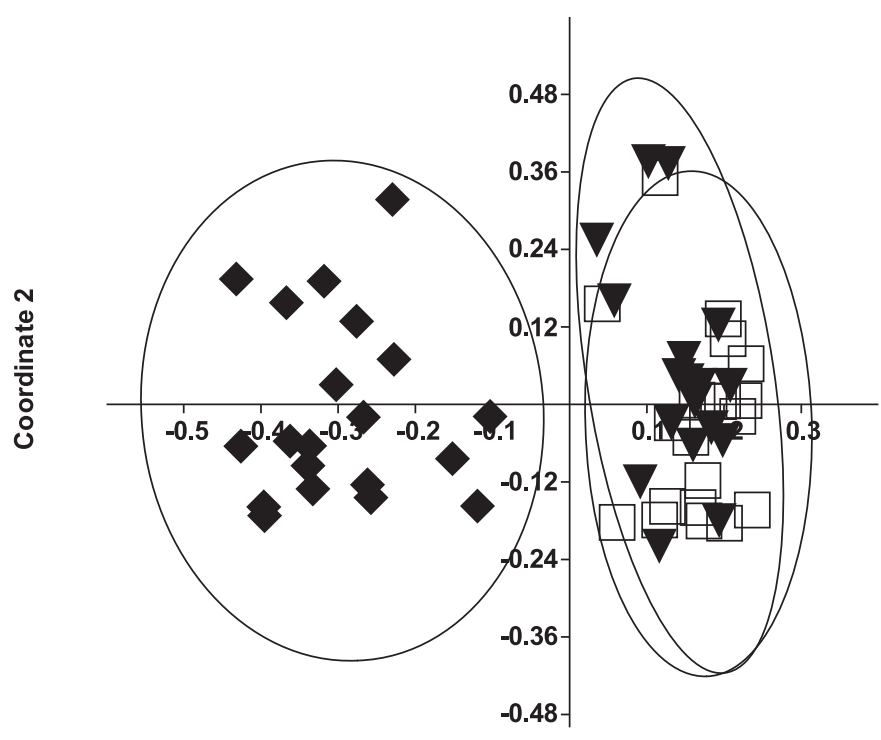

\section{Coordinate 1}

Fig. 5. Effect of preplant orchard soil treatments on fungal community composition detected in the rhizosphere of Gala apple at the end of the second growing season as assessed by nonmetric multidimensional scaling of operational taxonomic unit (OTU) data using the Bray-Curtis distance metric. OTUs were defined as sequences sharing $\geq 97 \%$ similarity with one another. Ellipses denote $95 \%$ confidence limits; $\square=$ no-treatment control; $\boldsymbol{\nabla}=$ preplant $1,3-$ dichloropropene/chloropicrin fumigation; $\bullet=$ preplant Brassica junceaSinapis alba seed meal soil amendment.

TABLE 6. Attributes of apple rhizosphere bacterial community diversity based upon relative abundance of operational taxonomic units (OTUs) (97\%)w

\begin{tabular}{|c|c|c|c|c|c|c|}
\hline Rootstock & Soil treatment ${ }^{\mathrm{x}}$ & Sequences per sample ${ }^{y}$ & Number of OTUs $(97 \%)^{\mathrm{z}}$ & Shannon H & Chao 1 & Dominance \\
\hline M9 & Control & 7,146 & $494 \pm 38$ & $5.11 \pm 0.17$ & $578 \pm 48$ & $0.013 \pm 0.006$ \\
\hline G11 & Control & 5,697 & $507 \pm 37$ & $5.14 \pm 0.07$ & $610 \pm 49$ & $0.012 \pm 0.001$ \\
\hline M9 & SM & 7,484 & $451 \pm 31$ & $4.74 \pm 0.10$ & $534 \pm 42$ & $0.013 \pm 0.002$ \\
\hline M9 & Telone-C17 & 7,476 & $514 \pm 44$ & $5.18 \pm 0.09$ & $613 \pm 49$ & $0.011 \pm 0.002$ \\
\hline G11 & Telone-C17 & 7,302 & $510 \pm 36$ & $5.16 \pm 0.06$ & $612 \pm 59$ & $0.013 \pm 0.005$ \\
\hline
\end{tabular}

w Data are indicated as mean \pm standard deviation.

x Treatment designations are as follows: Control = no preplant soil treatment, $\mathrm{SM}=$ preplant Brassica juncea-Sinapis alba seed meal soil amendment, Telone-C17 = preplant 1,3-dichloropropene/chloropicrin soil fumigation.

y $n=10$.

${ }^{\mathrm{z}}$ OTUs are defined as sequences sharing $>97 \%$ similarity. 
of soil suppressiveness to Pythium spp. in response to B. juncea SM amendment was AITC dependent but functioned through the resident soil biology. AITC induced the development of a fungal community in which Trichoderma spp., a group demonstrating resistance to AITC $(19,42)$, became dominant $(62)$. The functional attributes of the SM-amended soil system that led to prolonged suppression of $P$. penetrans in this study were not determined but the composition and relative diversity of fungal and bacterial communities from the rhizosphere of apple cultivated in SMamended soil were demonstrably different than either the control or fumigated soil treatments at the SR orchard. Certain nematophagous fungi, including Arthrobotrys and Paecilomyces spp. were exclusively or more commonly isolated from the roots of Gala apple seedlings cultivated in orchard soil amended with B. napus SM (M. Mazzola, unpublished data). In the current study, although present in low abundance, the nematophagous fungi Arthrobotrys spp., including Arthrobotrys conoides (17) and A. yunnanensis (45), as well as Dactylella oviparasitica (54), were detected exclusively in the rhizosphere of apple from the SM treatment, and absent from the rhizosphere fungal community detected in the control or fumigated soil treatments.

Previous studies have noted the effects of Brassica SM amendments on soil microbial community structure, and selective amplification of certain bacterial components such as Streptomyces spp. has been consistent across studies $(10,11,26,39)$. These studies were relatively short term in duration (4 to 12 weeks), yet certain reports have indicated that the microbial community in SMamended soil reverted to one that was similar to the nontreated soil within 28 days (61). In the current study, although the rhizosphere bacterial and fungal communities in fumigated soil had reverted to one indistinguishable from the control by the end of the second growing season, the same communities from SM-amended soil were clearly distinct from their counterparts in the nontreated control. In addition, the reduced microbial diversity detected in SMamended soils for studies of short duration (26) persisted in the apple rhizosphere for more than 2 years after soil treatment.

Specific elements of the soil microbial community which differed among soil treatments in short-term studies were not necessarily consistent with those observed in rhizosphere soil 2 years postplanting. For instance, whereas amplification of Streptomyces spp. densities in response to SM amendment was observed in shortterm studies $(10,11,26,39)$, in this field study, Streptomyces spp. were detected at lower abundance in rhizosphere soil from the SM treatment relative to the nontreated control or fumigation treatment 2 years after planting. In contrast, other actinobacteria were more prevalent in the rhizosphere of trees planted in SM-amended soil. Burkholderia spp., which are known to provide biological control of certain soilborne plant pathogens $(44,48)$ and whose elevated populations were associated with soil suppressiveness to Rhizoctonia root rot of apple (37), were significantly more abundant in the SM treatment than the control or fumigation treatments. Mortierella spp. were identified as a dominant component of the fungal community in SM-amended soils in this and previous studies regardless of soil incubation time (10,62). In contrast, Trichoderma spp., which initially responded positively to $B$. juncea SM amendment (62), displayed no difference in abundance in the rhizosphere of apple 2 years postplanting among soil treatments. Rather, Oidiodendron spp. were the dominant ascomycete detected, an organism that has been reported to provide control of oomycete plant pathogens such as Phytophthora cactorum (1). Continued transformation of the microbial community composition should not be unexpected as biomass degradation proceeds, resulting in a diversity of coproducts with potential to select for organisms possessing specific substrate utilization profiles.

A number of bacterial groups commonly associated with capacity to metabolize specific chemistries were maintained predominantly or exclusively in the rhizosphere of apple cultivated in SM-amended soils. Certain sulfur mineralizing bacteria were prevalent in the rhizosphere of the SM-cultivated apple, which likely can be attributed to the fact that the SM amendment contained approximately $1.6 \%$ sulfur $(3,40)$. Populations of other bacterial groups, such as Burkholderia spp. (47,52), Defluvibacter spp. (18), and Rhodanobacter lindaniclasticus (46), known to degrade recalcitrant chemistries including pesticides and industrial wastes, were also amplified in the SM treatment rhizosphere samples. Planting of soil with $B$. juncea was reported to enhance degradation of the herbicide atrazine (31) and the degradation rate was higher in nonautoclaved than autoclaved soil, indicating that microbial degradation, and not merely plant uptake, contributed to the response. The selective capacity of Brassica SM for bacterial groups, including Streptomyces, possessing the ability to utilize a broad spectrum of complex carbohydrates has been reported previously (5).

It is customarily implied that enhanced microbial community diversity is associated with enhanced soil ecosystem sustainability and resilience to disturbance $(9,28)$. However, the relationship between soil biodiversity and ecosystem function is not perceived to be universal $(59,61)$ and, in certain instances, may rely more on the presence of species with particular traits rather than species richness (9). The capacity of a soil system to suppress pathogen infestation and subsequent disease development has been associated with specific functional elements of the soil microbial community (63). Metagenome analysis of soils conducive and suppressive to potato common scab (50) and Fusarium wilt (32) indicated that the suppressive soil system possessed an elevated degree of bacterial diversity relative to the disease-conducive soil. In contrast, bacterial and fungal apple rhizosphere communities from the $B$. juncea$S$. alba SM-amended treatment that exhibited higher yields and reduced pathogen infestation exhibited reduced diversity relative to the disease-conducive fumigated soil.

In summary, the Brassicaceae SM formulations examined in this study effectively reduced disease incidence at both orchard sites resulting in tree growth performance that was equivalent or superior to that attained in response to the traditional control method of preplant fumigation. Although some phytotoxicity in response to SM amendment was observed, the effects were alleviated (or

TABLE 7. Attributes of apple rhizosphere fungal community diversity based upon relative abundance of operational taxonomic unit (OTUs)w

\begin{tabular}{|c|c|c|c|c|c|c|}
\hline Rootstock & Soil treatment ${ }^{\mathrm{x}}$ & Sequences per sample & Number of OTUs ${ }^{\mathrm{z}}$ & Shannon H & Chao 1 & Dominance \\
\hline M9 & Control & 5,727 & $154 \pm 29$ & $3.43 \pm 0.39$ & $179 \pm 39$ & $0.091 \pm 0.057$ \\
\hline G11 & Control & 5,697 & $165 \pm 29$ & $3.44 \pm 0.21$ & $196 \pm 34$ & $0.079 \pm 0.022$ \\
\hline M9 & SM & 5,241 & $82 \pm 31$ & $2.38 \pm 0.45$ & $100 \pm 24$ & $0.184 \pm 0.083$ \\
\hline M9 & Telone-C17 & 6,374 & $142 \pm 23$ & $3.27 \pm 0.24$ & $168 \pm 23$ & $0.084 \pm 0.028$ \\
\hline G11 & Telone-C17 & 5,173 & $141 \pm 23$ & $3.07 \pm 0.38$ & $165 \pm 28$ & $0.141 \pm 0.062$ \\
\hline
\end{tabular}

${ }^{\mathrm{w}}$ Data are indicated as mean \pm standard deviation.

x Treatment designations are as follows: Control $=$ no preplant soil treatment, $\mathrm{SM}=$ preplant Brassica juncea-Sinapis alba seed meal soil amendment, Telone-C17 $=$ preplant 1,3-dichloropropene/chloropicrin soil fumigation.

y $n=10$.

${ }^{\mathrm{z}}$ OTUs are defined as sequences sharing $>97 \%$ similarity. 
negated) in soil with higher organic matter content or simply by increasing the amount of time between application of the amendment and planting date. Overall, the consequence of the SM soil amendment to the rhizosphere microbial community may be more persistent than the effects realized during the 2-year period of this study because the communities were clearly distinct from either the control or fumigated treatments. Although the producer community commonly asserts the optimal benefit of preplant soil fumigation for orchard economic vitality on replant sites, together, these findings demonstrate that more sustainable and productive systems may be attained through targeted rather than indiscriminate management of orchard soil microbiology.

\section{ACKNOWLEDGMENTS}

This work was funded, in part, through a grant to M. Mazzola from the USDA NIFA Organic Agriculture Research and Extension Initiative Grants Program. We thank C. L. Reardon and T. C. Paulitz for critical review of the manuscript.

\section{LITERATURE CITED}

1. Alexander, B. J. R., and Stewart, A. 2001. Glasshouse screening for biological control agents of Phytophthora cactorum on apple (Malus domestica). N. Z. J. Crop Hortic. Sci. 29:159-169.

2. Bai, Y., Sun, Q., Zhao, C., Wen, D., and Tang, X. 2009. Aerobic degradation of pyridine by a new bacterial strain, Shinella zoogloeoides BC026. J. Ind. Microbiol. Biotechnol. 36:1391-1400.

3. Bell, J. M. 1984. Nutrients and toxicants in rapeseed meal: A review. J. Anim. Sci. 58:996-1010.

4. Blum, U., Shafer, S. R., and Lehman, M. E. 1999. Evidence for inhibitory allelopathic interactions involving phenolic acids in field soils: Concepts vs an experimental model. CRC Crit. Rev. Plant Sci. 18: 673-693

5. Brabban, A. D., and Edwards, C. 1996. Characterization of growth and product formation by a thermophilic streptomycete grown in a particulate rapemeal-derived liquid medium. J. Appl. Bacteriol. 80:651-658.

6. Brown, J., Davis, J. B., Erickson, D. A., Brown, A. P., and Seip, L. 1997. Registration of 'IdaGold' yellow mustard. Crop Sci. 38:541.

7. Brown, J., Davis, J. B., Erickson, D. A., Seip, L., and Gosselin, T. 2004. Registration of 'Pacific Gold' condiment yellow mustard. Crop Sci. 44:2271-2272.

8. Brown, J., Wysocki, D., Davis, J. B., Erickson, D. A., Seip, L., Ott, S., and Gosselin, T. 2005. Registration of 'Athena' winter rapeseed. Crop Sci. 45: 800-801.

9. Brussaard, L., de Ruiter, P. C., and Brown, G. G. 2007. Soil biodiversity for agricultural sustainability. Agric. Ecosyst. Environ. 121:233-244.

10. Cohen, M. F., and Mazzola, M. 2006. Effects of Brassica napus seed meal amendment on soil populations of resident bacteria and Naegleria americana, and the unsuitability of arachidonic acid as a protozoanspecific marker. J. Protozool. Res. 16:16-25.

11. Cohen, M. F., and Mazzola, M. 2006. Impact of resident bacteria, nitric oxide emission and particle size on root infection by Pythium spp. and $R$. solani AG-5 in Brassica napus seed meal amended soils. Plant Soil 286:75-86.

12. Covey, R. P., Jr., Benson, N. R., and Haglund, W. A. 1979. Effect of soil fumigation on the apple replant disease in Washington. Phytopathology 69:684-686.

13. DeSantis, T. Z., Hugenholtz, P., Larsen, N., Rojas, M., Brodie, E. L., Keller, K., Huber, T., Dalevi, D., Hu, P., and Andersen, G. L. 2006. Greengenes, a chimera-checked 16S rRNA gene database and workbench compatible with ARB. Appl. Environ. Microbiol. 72:5069-5072.

14. Dowd, S. E., Hanson, J. D., Rees, E., Wolcott, R. D., Zischau, A. M., Sun, Y., White, J., Smith, D. M., Kennedy, J., and Jones, C. E. 2011. Survey of fungi and yeast in polymicrobial infections in chronic wounds. J. Wound Care 20:40-47.

15. Dowd, S. E., Sun, Y., Wolcott, R. D., Domingo, A., and Carroll J. A. 2008. Bacterial tag-encoded FLX amplicon pyrosequencing (bTEFAP) for microbiome studies: Bacterial diversity in the ileum of newly weaned Salmonella-infected pigs. Foodborne Pathog. Dis. 5:459-472.

16. Edgar, R. C. 2010. Search and clustering orders of magnitude faster than BLAST. Bioinformatics 26:2460-2461.

17. Falbo, M. K., Soccol, V. T., Sandini, I. E., Vicente, V. A., Robi, D., and Soccol, C. R. 2013. Isolation and characterization of the nematophagous fungus Arthrobotrys conoides. Parasitol. Res. 112:177-185.

18. Fritsche, K., Auling, G., Andreesen, J. R., and Lechner, U. 1999. Defluvibacter lusatiae gen. nov., sp. nov., a new chlorophenol-degrading member of the alpha-2 subgroup of proteobacteria. Syst. Appl. Microbiol. 22:197-204.

19. Galletti, S., Sala, E., Leoni, O., Burzi, P. L., and Cerato, C. 2008. Trichoderma spp. tolerance to Brassica carinata seed meal for a combined use in biofumigation. Biol. Control 45:319-327.

20. Gardes, M., Fortin, J., White, T. J., Bruns, T. D., and Taylor, J. W. 1991. Identification of indigenous and introduced symbiotic fungi in ectomycorrhizae by amplification of the nuclear and mitochondrial ribosomal DNA. Can. J. Bot. 69:180-190.

21. Hammer, Ø., Harper, D. A. T., and Ryan, P. D. 2001. PAST: Paleontological statistics software package for education and data analysis. Palaeontol. Electron. 4:1-9.

22. Handiseni, M., Brown, J., Zemetra, R., and Mazzola, M. 2011. Herbicidal activity of Brassicaceae seed meal on wild oat (Avena fatua), Italian rye grass (Lolium multiflorum), redroot pigweed (Amaranthus retroflex) and prickly lettuce (Lactuca serriola). Weed Technol. 25:127-134.

23. Handiseni, M., Brown, J., Zemetra, R., and Mazzola, M. 2013. Effect of Brassicaceae seed meals with different glucosinolate profiles on Rhizoctonia root rot of wheat. Crop Prot. 48:1-5.

24. Handl, S., Dowd, S. E., Garcia-Mazcorro, J. F., Steiner, J. M., and Suchodolski, J. S. 2011. Massive parallel 16S rRNA gene pyrosequencing reveals highly diverse fecal bacterial and fungal communities in healthy dogs and cats. FEMS Microbiol. Ecol. 76:301-310.

25. Hewavitharana, S. S., Ruddell, D., and Mazzola, M. 2014. Carbon sourcedependent antifungal and nematicidal volatiles derived during anaerobic soil disinfestation. Eur. J. Plant Pathol. 140:39-52.

26. Hollister, E. B., Hu, P., Wang, A. S., Hons, F. M., and Gentry, T. J. 2013. Differential impacts of brassicaceous and nonbrassicaceous oilseed meals on soil bacteria and fungal communities. FEMS Microbiol. Ecol. 83: 632-641.

27. Ishak, H. D., Plowes, R., Sen, R., Kellner, K., Meyer, E., Estrada, D. A., Dowd, S. E., and Mueller, U. G. 2011. Bacterial diversity in Solenopsis invicta and Solenopsis geminate ant colonies characterized by $16 \mathrm{~S}$ amplicon 454 pyrosequencing. Microb. Ecol. 61:821-831.

28. Ives, A. R., and Carpenter, S. R. 2007. Stability and diversity of ecosystems. Science 317:58-62.

29. Jaffee, B. A., Abawi, G. S., and Mai, W. F. 1982. Fungi associated with roots of apple seedlings grown in soil from an apple replant site. Plant Dis. 66:942-944.

30. Jaffee, B. A., Abawi, G. S., and Mai, W. F. 1982. Role of soil microflora and Pratylenchus penetrans in an apple replant disease. Phytopathology 72:247-251

31. Khan, S. J., and Gaikwad, R. S. 2013. Phytoremediation potential of Brassica juncea L. with reference to Atrazine. Int. Res. J. Sci. Eng. 1:5-9.

32. Klein, E., Ofek, M., Katan, J., Minz, D., and Gamliel, A. 2013. Soil suppressiveness to Fusarium disease: Shifts in root microbiome associated with reduction of pathogen root colonization. Phytopathology 103: 23-33.

33. Mai, W. F., and Abawi, G. S. 1981. Controlling replant disease of stone fruits in northeastern United States by preplant fumigation. Plant Dis. 65: 859-864.

34. Makino, T., Takahashi, T., Sakurai, Y., and Nanzyo, M. 1996. Influence of soil chemical properties on adsorption and oxidation of phenolic acids in soil suspension. Soil Sci. Plant Nutr. 42:867-879.

35. Masai, E., Yamada, A., Healy, J. M., Hatta, T., Kimbara, K., Fukuda, M., and Yano, K. 1995. Characterization of biphenyl catabolic genes of grampositive polychlorinated biphenyl degrader Rhodococcus sp. strain RHA1. Appl. Environ. Microbiol. 61:2079-2085.

36. Mazzola, M. 1998. Elucidation of the microbial complex having a causal role in the development of apple replant disease in Washington. Phytopathology 88:930-938.

37. Mazzola, M. 1999. Transformation of soil microbial community structure and Rhizoctonia-suppressive potential in response to apple roots. Phytopathology 89:920-927.

38. Mazzola, M., and Brown, J. 2010. Efficacy of brassicaceous seed meal formulations for the control of apple replant disease in organic and conventional orchard production systems. Plant Dis. 94:835-842.

39. Mazzola, M., Brown, J., Izzo, A., and Cohen, M. F. 2007. Mechanism of action and efficacy of seed meal-induced suppression of pathogens inciting apple replant disease differ in a Brassicaceae species and timedependent manner. Phytopathology 97:454-460.

40. Mazzola, M., Brown, J., Zhao, X., Izzo, A., and Fazio, G. 2009. Interaction of brassicaceous seed meal and apple rootstock on recovery of Pythium spp. and Pratylenchus penetrans from roots grown in replant soils. Plant Dis. 93:51-57.

41. Mazzola, M., Granatstein, D. M., Elfving, D. C., and Mullinix, K. 2001. Suppression of specific apple root pathogens by Brassica napus seed meal amendment regardless of glucosinolate content. Phytopathology 91: 673-679. 
42. Mazzola, M., and Manici, L. M. 2012. Apple replant disease: Role of microbial ecology in cause and control. Annu. Rev. Phytopathol. 50:45-65.

43. Mazzola, M., and Mullinix, K. 2005. Comparative field efficacy of management strategies containing Brassica napus seed meal or green manure for the control of apple replant disease. Plant Dis. 89:1207-1213.

44. McLoughlin, T. J., Quinn, J. P., Bettermann, A., and Bookland, R. 1992. Pseudomonas cepacia suppression of sunflower wilt fungus and role of antifungal compounds in controlling the disease. Appl. Environ. Microbiol. 58:1760-1763.

45. Mo, M. H., Huang, X. W., Zhou, W., Huang, Y., Hao, Y. E., and Zhang, K. Q. 2005. Arthrobotrys yunnanensis sp. nov., the fourth anamorph of Orbilia auricolor. Fungal Divers. 18:107-115.

46. Nalin, R., Simonet, P., Vogel, T. M., and Normand, P. 1999. Rhodanobacter lindaniclasticus gen. nov., sp. nov., a lindane-degrading bacterium. Int. J. Syst. Bacteriol. 49:19-23.

47. Nelson, M. J., Montgomery, S. O., Mahaffey, W. R., and Pritchard, P. H. 1987. Biodegradation of trichloroethylene and involvement of an aromatic biodegradative pathway. Appl. Environ. Microbiol. 53:949-954.

48. Parke, J. L., Rand, R. E., Joy, A. E., and King, E. B. 1991. Biological control of Pythium damping-off and Aphanomyces root rot of peas by application of Pseudomonas cepacia or P. fluorescens to seed. Plant Dis. 75:987-992.

49. Rice, A. R., Johnson-Maynard, J. L., Thill, D. C., and Morra, M. J. 2007. Vegetable crop emergence and weed control following amendment with different Brassicaceae seed meals. Renew. Agric. Food Syst. 22:204-212.

50. Rosenzweig, N., Tiedje, J. M., Quensen, J. F., III, Meng, Q., and Hao, J. J. 2012. Microbial communities associated with potato common scab suppressive soil determined by pyrosequencing analyses. Plant Dis. 96: 718-725.

51. Santo, G. S., and Wilson, J. H. 1990. Effects of fenamiphos on Pratylenchus penetrans and growth of apple. J. Nematol. 22:779-782.

52. Shields, M. S., and Reagin, M. J. 1992. Selection of a Pseudomonas cepacia strain constitutive for the degradation of trichloroethylene. Appl. Environ. Microbiol. 58:3977-3983.

53. Smith, T. J.1995. Orchard Update. Wash. State Univ. Coop. Ext. Bull. September issue. Pullman.

54. Stirling, G. R., and Mankau, R. 1978. Dactylella oviparasitica, a new fungal parasite of Meloidogyne eggs. Mycologia 70:774-783.
55. Tewoldemedhin, Y. T., Mazzola, M., Labuschagne, I., and McLeod, A. 2011. Towards understanding the etiology of apple replant disease in South Africa using a multiphasic approach. Soil Biol. Biochem. 43: 1917-1927.

56. Trout, T. 2005. Impact of township caps on Telone use in California. Pages 127.1-127.8 in: Proc. Annu. Int. Conf. Methyl Bromide Alternatives and Emissions Reductions, MBAO, Fresno, CA.

57. U.S. Environmental Protection Agency. 2012. Phase 2 site-specific fumigant management plans and post-application summaries. EPA Factsheet 735-F-12-007.

58. Utkhede, R. S., Vrain, T. C., and Yorston, J. M. 1992. Effects of nematodes, fungi and bacteria on growth of young apple trees grown in replant disease soils. Plant Soil 139:1-6.

59. van der Heijden, M. G. A., and Wagg, C. 2013. Soil microbial diversity and agro-ecosystem functioning. Plant Soil 363:1-5.

60. Vaughn, S. F., Palmquist, D. E., Duval, S. M., and Berhow, M. A. 2006. Herbicidal activity of glucosinolate-containing seed meals. Weed Sci. 54: 743-748.

61. Wang, A. S., Ping, H., Hollister, E. B., Rothlisberger, K. L., Somenahally, A., Provin, T. L., Hons, F. M., and Gentry, T. J. 2012. Impact of Indian mustard (Brassica juncea) and flax (Linum usitatissimum) seed meal applications on soil carbon, nitrogen and microbial dynamics. Appl. Environ. Soil Sci. Article ID 351609.

62. Weerakoon, D. M. N., Reardon, C. L., Paulitz, T. C., Izzo, A. D., and Mazzola, M. 2012. Long-term suppression of Pythium abappressorium induced by Brassica juncea seed meal amendment is biologically mediated. Soil Biol. Biochem. 51:44-52.

63. Weller, D. M., Raaijmakers, J. M., Gardener, B. B. M., and Thomashow, L. S. 2002. Microbial populations responsible for specific soil suppressiveness to plant pathogens. Annu. Rev. Phytopathol. 40:309-348.

64. White, T. J., Bruns, T., Lee, S., and Taylor, J. 1990. Amplification and direct sequencing of fungal ribosomal RNA genes for phylogenetics. Pages 315-324. in: PCR Protocols: A Guide to Methods and Applications. M. A. Innis, D. H. Gelfand, J. J. Sninsky, and T. J. White, eds. Academic Press, San Diego, CA.

65. Wilhelm, S., Storken, R. C., and Sagen, J. E. 1961. Verticillium wilt of strawberry controlled by fumigation of soil with chloropicrin and chloropicrin-methyl bromide mixtures. Phytopathology 51:744-748. 